Ana Maria Doimo. A vez e a voz do popular: movimentos populares e participação política no Brasil Pós-70, Rio de Janeiro, ANPOCS/Relume Dumará, 1995.

\title{
Movimentos Populares e Sua Crise: Um Novo Arranjo Conceitual
}

\author{
Carolina Moreira Marques \\ Mestranda em Sociologia/ USP, Bolsista do CNPq
}

Este livro é o resultado de uma tese de doutorado que foi defendida na FFLCH-USP em 1993 e que ganhou o Prêmio ANPOCS em 1994. O material de pesquisa foi obtido através de um extenso trabalho de campo, em que se completam a "participação observante" e a "observação participante" da autora, e também é constituído por uma impressionante quantidade de documentos de primeira mão dos movimentos (1.976) e de instituições ligadas a eles (200), organizados e apresentados ao longo do livro em tabelas e quadros muito interessantes. Quanto à análise, Ana Maria Doimo parte do problema atual da denominada "crise dos movimentos sociais", mas se recusa a explicá-la com um excesso de otimismo ou pessimismo, preferindo reconstruir o problema a partir de um estudo teórico e empírico bastante refinado.

O livro é dividido em duas partes: a primeira trata do problema teórico e a segunda, do problema empírico.

Assim, o texto inicia-se com uma discussão sobre os termos "novos movimentos sociais" e "movimentos populares", freqüentemente usados para definir os movimentos sociais no Brasil pós-70. A autora vê alguns problemas nesta terminologia.

O principal talvez seja de que o debate que utiliza estes termos caracteriza-se por uma reflexão dicotômica: tratar-se-iam hoje de grupos organizados espontaneamente com ênfase no aspecto cultural, enquanto antes tratar-se-ia da classe trabalhadora organizada racionalmente em partidos e sindicatos com ênfase no aspecto econômico; assim, os primeiros negariam e os segundos afirmariam a institucionalidade política. Neste sentido, são discutidos os trabalhos de Eric Hobsbawm, Alain Touraine, Tilman Evers, Ernesto Laclau, Claus Offe, José Álvaro Moisés, Francisco Weffort, Francisco de Oliveira, entre outros.

Ana Maria Doimo propõe, então, que tal dicotomia reflita na verdade uma ambigüidade interna aos próprios movimentos, e esta tese será desenvolvida em toda segunda parte do livro. Neste sentido, um novo arranjo conceitual é elaborado.

Em primeiro lugar, para a autora, o que distingue os ditos "novos movimentos sociais" ou "movimentos populares" é o recurso à "ação direta". Ana Maria Doimo traz esta noção para o centro de sua concepção teórica, mostrando como os "conflitos de ação direta" emergem num lugar entre o Estado, o mercado e a cultura; que se constituem enquanto uma nova forma de reinvindicação por bens coletivos, tendo como seus agenciadores instituições que não têm a política como seu fundamento. Mais, acima de tudo, os "movimentos de ação direta" se configuram enquanto "campos ético-políticos". 
E, para compreender como isso se dá, a autora analisa cinco movimentos: o de Custo de Vida, o de Moradia, o de Luta Contra o Desemprego, o de Saúde e o de Transporte Coletivo. Ana Maria Doimo traça o histórico de cada um destes movimentos no período de 1975 a 1990 no Brasil. E vai além: mostra como, apesar da dispersão no espaço e no tempo, eles têm "conexões ativas" que são estabelecidas através de interlocutores comuns: a intelectualidade acadêmica, os agrupamentos de esquerda, as ONGs, o ecumenismo secular, e, principalmente, a Igreja Católica. Interlocutores estes que recuperaram nas suas ações e reflexões a idéia de "povo como sujeito de sua própria história". Uma idéia que, segundo a autora, é a metáfora de algo fundamental: um "código ético-político" comum aos movimentos. O livro mostra como estes "códigos ético-políticos" se difundem através do mecanismo de "troca de experiências" dentro de cada movimento e entre movimentos diferentes, e também da multiplicidade de práticas de “educação popular", entre elas: a educação popular em si (concebida por Paulo Freire), a comunicação popular (imprensa escrita, rádio, vídeo, teatro, etc.), a dinâmica de grupo, a pesquisa participante e, fundamentalmente, a Igreja popular.

E aqui, a autora radicaliza a interpretação quanto ao papel da Igreja Católica em relação aos movimentos sociais. Ao contrário da literatura especializada que a entende no máximo como um agente articulador externo, para Ana Maria Doimo, a Igreja é a referência simbólica central dos movimentos. A autora mostra isso através da carga religiosa dos discursos, músicas e ilustrações dos mesmos, fartamente exemplificados ao longo do livro. Mais do que isso, mostra como a Igreja popular não era uma dissidência da Igreja "oficial", ao contrário, um pouco mais ou um pouco menos em diferentes momentos, a primeira teve a legitimação da segunda, através de apoio material, organizativo e simbólico.

Mas como este "código ético-político" pode atingir movimentos tão dispersos no tempo e no espaço? Através de "redes sociais" que articulam não só os movimentos entre si, como também estes com outras instituições. A autora constrói então uma tipologia destas "redes sociais". Por um lado, podem ser "territoriais", tanto locais como nacionais, constituindo-se basicamente no rastro da Igreja Católica e do ecumenismo secular. Por outro lado, podem ser "temáticas", ou seja, com funções especializadas em relação aos movimentos: de intermediação de projetos, de produção de saber técnico-competente, de elaboração de recursos comunicacionais, de registro da memória ativa e de costura de solidariedade à distância; e aqui o papel fundamental é das ONGs, que, entretanto, incorporam tanto a intelectualidade acadêmica quanto agrupamentos de esquerda, e se cruzam com a Igreja Católica e com o ecumenismo secular. Finalmente, na intersecção entre as duas anteriores - das quais são citados inúmeros exemplos - , têm-se as "redes sociais de influência" que dão uma certa diretividade aos movimentos e são responsáveis pelas disputas em torno dos recursos de poder; é o caso, por exemplo, do PT e dos grupos que elaboram iniciativas de emendas constitucionais. Assim, se quanto às "redes sociais territoriais e temáticas" tem-se um distanciamento em relação à institucionalidade política tradicional, quanto às "redes sociais de influência" ocorre o inverso. Mas, como já dito anteriormente, esta relação com a institucionalidade, para Ana Maria Doimo, não reflete uma dicotomia e sim uma ambigüidade.

Para a autora, a causa desta ambigüidade é o fato do "código ético-político" dos movimentos ter suas raízes numa instituição que, embora funcione segundo uma "lógica consensual-solidarística" oposta à racionalidade da política institucional, nunca deixou de 
se interessar pelos negócios de Estado. Esta instituição é a Igreja Católica. Mas também é causa desta ambigüidade o fato dos movimentos se constituírem enquanto "conflitos de ação direta", que têm uma dupla face: uma "expressivo-disruptiva" e outra "integrativocorporativa". A primeira, marcada pela negação total da institucionalidade política tradicional e caracterizada pela busca de transformações estruturais através de condutas paralelas de "ação direta" centradas no modelo comunitário de organização; e a segunda, marcada por uma afirmação seletiva da institucionalidade política tradicional e caracterizada pela busca de readequações conjunturais através da linguagem dos direitos e da cidadania. Segundo a autora, historicamente, os movimentos manifestaram mais a primeira durante o regime militar e mais a segunda durante a abertura política.

Assim, a dita "crise dos movimentos sociais", embora sempre latente, hoje seria evidente porque todos elementos que davam um certo equilíbrio a estas ambigüidades se redefiniram e não desempenham mais esta função. A intelectualidade acadêmica abandonou o otimismo teórico em relação aos movimentos e dedica-se à temática da transição política e da reengenharia institucional; os agrupamentos de esquerda, antes comprometidos com a revolução, assumem crescentes compromissos com o sistema partidário e com o Estado; as ONGs, inclusive as de caráter ecumênico secular, incorporaram critérios de eficácia e têm se dedicado mais a ações propositivas de políticas públicas do que ações de assessoria aos movimentos, até porque a idéia de educação popular vem perdendo força; e, principalmente, a Igreja Católica "oficial" mudou sua diretividade, o que representou um recuo da Igreja Católica popular.

Para Ana Maria Doimo, as conseqüências destas mudanças para os movimentos são fundamentais: por um lado, negativamente, a desagregação das "redes sociais", o decréscimo das reivindicações de "ação direta", a desarticulação do universo simbólico que sustenta o "campo ético-político"; mas, por outro lado, positivamente, a ênfase cada vez maior nas atitudes ativo-propositivas de alteração dos aparatos político-administrativos, a conquista de dispositivos institucionais da participação direta e semi-direta, a conquista e a manutenção dos direitos de cidadania. Assim, segundo a autora, ganharam os movimentos que investiram nestes últimos aspectos e perderam os que insistiram nos primeiros. Portanto, a despeito da "crise", o livro mostra como os movimentos obtiveram vários ganhos: a construção partidária, a criação de uma central de movimentos populares, a institucionalização de novos direitos sociais e a interferência no sistema de representação de interesses pela via conselhista.

Enfim, este livro traz uma nova elaboração teórica a partir de uma pesquisa empírica riquíssima e, por isso, interessa tanto àqueles que querem se aproximar do tema, pois oferece um quadro teórico e empírico bastante amplo, como também àqueles que já estudam o tema e buscam novas informações e abordagens sobre o mesmo assunto. 